\title{
Erosion and Flood Susceptibility Evaluation in a Catchment of Kopet-Dagh Mountains Using EPM and RFM in GIS
}

Siamak Baharvand ( $\nabla$ s.baharvand@khoiau.ac.ir)

Islamic Azad University of Khorramabad https://orcid.org/0000-0002-9190-7534

Biswajeet Pardhan

University of Technology Sydney

\section{Research Article}

Keywords: Erosion Potential Method (EPM), Rational Flood Model (RFM), Geographical Information System (GIS), Susceptibility Evaluation, Kopet-Dagh, Iran

Posted Date: January 19th, 2022

DOI: https://doi.org/10.21203/rs.3.rs-1133943/v1

License: (c) (i) This work is licensed under a Creative Commons Attribution 4.0 International License.

Read Full License 


\title{
Erosion and flood susceptibility evaluation in a catchment of Kopet- Dagh Mountains using EPM and RFM in GIS
}

\author{
Siamak Baharvand ${ }^{1^{*}} \&$ Biswajeet Pardhan ${ }^{2}$ \\ Department of Geology, Islamic Azad University of Khorramabad, Khorramabad, Iran. \\ School of Information, Systems and Modelling, University Technology of Sydney, \\ Sydney, Australia \\ Email: s.baharvand@khoiau.ac.ir
}

\begin{abstract}
:
Erosion and flood events can damage soils, water, quality, and sediment transportation, causing many cumulative hazards. In developing countries, such as Iran, the empirical models, which are low-cost procedures to mitigate the environmental hazards, are necessary to plan the watersheds. Hence, the main aim of this study is to evaluate erosion and flood susceptibility using empirical models of erosion potential method (EPM) and rational flood model (RFM) to prioritize the GIS-based prone zones in a catchment of the Kopet-Dagh Mountains. The results revealed that the heavy classes of erosion and flood susceptibility include $40.4-58.2 \%$ of the total study area, dominantly in the upstream catchments. The correlation test revealed a strong, significant, and direct association ( $\mathrm{R}$ equal to 0.705 ) between $W$ and $Q p$ at the $99 \%$ confidence level. Consequently, the results of our research indicated the prioritization of the three subcatchments based on their slight sensitivity and susceptibility to occurrences of soil erosion and flood events through future spatial developments. Ultimately, the model validity explained the AUC (area under the curve) values averagely equal to 0.898 and 0.917 for erosion and flood susceptibility evaluations (i.e., EPM and RFM), explaining the very good performance of the models and excellent sensitivities.
\end{abstract}

Keywords: Erosion Potential Method (EPM), Rational Flood Model (RFM), Geographical Information System (GIS), Susceptibility Evaluation, Kopet-Dagh, Iran 


\section{Introduction}

Investigating the nature of the catchments and studying the drainage basin from many aspects such as flooding, erosion, and sedimentation have an important role in environmental planning (Brierley and Fryirs 2006, Ahmadi et al. 2020). Erosion and flood events can trigger damages to soils, water, quality, and sediment transportation, causing many cumulative hazards such as land creep and mudflow (Ebrahimi et al. 2021). Evaluation of soil erosion and a flash flood is a planning procedure to combat the threats in each watershed (Pandey et al. 2007). Both soil erosion and floods cause billions of dollars of damage to natural resources and agriculture, particularly in developing countries, where agriculture is the foundation of their economy (Mosavi et al. 2020a).

Floods are often accompanied by severe soil erosion and high sediment concentrations, leading to higher sediment load (Coppus and Imeson 2002, Dai and Lu 2010). Several studies have modeled the susceptibility evaluation and mapping for the flood hazard (e.g., Bui et al. 2018, Zhao et al. 2018a, Janizadeh et al. 2019, Hosseini et al. 2020, Pham et al. 2020) and soil erosion (e.g., Avand et al. 2019, Gayen et al. 2019, Moradi et al. 2019, Amiri and Pourghasemi 2020, Mosavi et al. 2020b). Susceptibility models significantly contribute to accurately identifying the prone zones to implement and develop watershed programs such as flood and soil erosion control (Azareh et al. 2019). Susceptibility evaluation attempts to provide insight for prevention, planning the mitigation actions, and adaptation to extremes to conserve land and water resources in the watersheds (Mosavi et al. 2020a).

In this regard, the erosion susceptibility models are used to evaluate erosion-prone areas concerning land characteristics and the sedimentary potentials of the watersheds (Feng et al. 2010), where water conservation programs are proposed (Fox et al. 2006). Many empirical methods have been developed in the scale of the catchments to evaluate erosion the sedimentation (Noori et al. 2016), such as the universal soil loss equation (USLE) (Auerswald et al. 2014, Ebrahimi et al. 2021), revised or modified USLE (Baskan et al. 2010, Zhao et al. 2018b), water erosion prediction project (WEPP) (Singh et al. 2011, Srivastava et al. 2015), pacific southwest interagency committee (PSIAC) (Daneshvar and Bagherzadeh 2012, Bagherzadeh and Daneshvar 2013) and erosion 
potential method (EPM) (Bagherzadeh and Daneshvar 2011, Ahmadi et al. 2020). Among the abovementioned methods, the applicability of the EPM in analyzing erosion potential and spatial data manipulation in GIS is appropriate (Mohammadi et al. 2021). Besides, flood susceptibility models are the proper way to mitigate the human and economic damages (Tingsanchali 2012), utilizing the empirical and rational procedures ( $\mathrm{Su}$ 2017), where the increasing trend flash floods are observed under the abrupt changes of the hydro-climatic condition (Huang et al. 2017, Ahmadi and Moradkhani 2019, Mihu-Pintilie et al. 2019). For this purpose, the rational flood models (RFM) belong to a group of hydrological models, which concludes the unit of analysis as an integrated value (Aja et al. 2020).

The aforementioned empirical procedures, which are based on natural descriptors of the catchments, have advantages to research because of validation of the model estimations and fewer input-data parameters compared with the process-based models (Schoenau et al. 2008, Lazzari et al. 2015). In developing countries like Iran, direct erosion and flood measurement and analysis in the watersheds are very time-consuming and costly (Spalevic et al. 2020, Mohammadi et al. 2021). Therefore, the use of empirical models is very necessary to environmental plan the watersheds. Hence, the main aim of this study is to evaluate erosion and flood susceptibility using empirical models of EPM and RFM to prioritize the GIS-based prone zones in a catchment of the Kopet-Dagh Mountains. The study area has some natural and cultural touristic attractions and nowadays has been selected as the main destination of eco-tourism and recreation activities in northeastern Iran, particularly for Mashhad city. The important characteristic of the study area is its geological setting of limestone units and carbonate rocks, which are susceptible to erosion and flood events and have the most sensitivity regarding Karst and water dissolution (Ebrahimi et al. 2019). Hence, the present study should be exposed the prone zones of the study area for future spatial development plans. We anticipate that this research's output can be considered a low-cost procedure to mitigate the environmental hazards and losses caused by flood and erosion events. 


\section{Geographical setting of the study area}

The Qarasu watershed with an area of $14.2 \mathrm{Km}^{2}$ between latitudes $36^{\circ} 56^{\prime}-36^{\circ} 59^{\prime} \mathrm{N}$ and longitudes $59^{\circ} 39^{\prime}-59^{\circ} 43^{\prime} \mathrm{E}$ is located in the northern side of Kopet-Dagh Mountains, in Kalat region, northeastern Iran. On a regional scale, the Qarasu catchment and Kalat region, in the vicinity to the border of Turkmenistan and Iran, are the highland areas with many natural phenomena, including geo parks, reserves, eco heritages, and historical touristic sites (Ebrahimi et al. 2019). Nowadays, it has been selected as the main destination of eco-tourism and recreation activities in northeastern Iran around Mashhad city (Fig. 1). From the natural viewpoint, the Kopet-Dagh Mountains are from a basin of sedimentary succession, which formed by the convergence of Central Iran and Eurasian plates following the Middle Triassic (Berberian and King 1981, Alavi et al. 1997), and continuous sediment depositions took place from the Jurassic and Cretaceous (Mahboubi et al. 2006). According to the digital elevation model (DEM) data, the topographical elevation varies between $2500 \mathrm{~m}$ a.s.1 at the south and $1000 \mathrm{~m}$ a.s.1 at the north with $>75 \%$ of the area $>1400 \mathrm{~m}$ (Fig. 2). The semi-arid climate features the study area with a mean annual temperature of $13{ }^{\circ} \mathrm{C}$ and annual precipitation of $400 \mathrm{~mm}$. The rainiest and driest seasons occur in March and August, with the mean precipitation of $\sim 50$ and $<5 \mathrm{~mm}$, respectively. The catchment was divided into 14 homogeneous terrain units of sub-catchments based on the visual interpretation of satellite image and DEM data (Fig. 3). The surface area in the sub-catchments varies between $0.4 \mathrm{~km}^{2}$ (no. 11) and $1.8 \mathrm{~km}^{2}$ (no. 6).

\section{Data and methods}

\subsection{Data preparation}

The required data for soil erosion and flood susceptibility evaluation were remotely obtained from some global datasets with spatial grid pixels and time series, focusing on the geographical coordination of the study area equal $36-37^{\circ} \mathrm{N}$ and $59-60^{\circ} \mathrm{E}$. The geological data were extracted from the drawing sheets at the 1:100,000 scale via the Geological Survey of Iran (GSI 2015). Therefore, topographical layouts were derived from a global digital elevation model (DEM) via the National Aeronautics and Space Administration (NASA 2011). The soil units of the study area were extracted from the 

global soil-grid dataset via https://soilgrids.org, and land use types and covers were considered from the global land-use/ land-cover (LULC) database via https://lpdaac.usgs.gov, retrieved from satellite products in 2010. The time-series of daily-rainfall data was collected from the geospatial interactive online visualization and analysis infrastructure (GIOVANNI) program for 2016-2020 via https://giovanni.gsfc.nasa.gov. The aforementioned data were processed in GIS ver. 10.4 and SPSS ver. 16.1 to produce the spatial layers and statistical attributes of the effective parameters of the EPM and RFM equations through the soil erosion and flood susceptibility evaluation.

\subsection{Erosion model}

The erosion potential method (EPM), which has been developed by Gavrilović (1988), can qualify the erosion severity and the total sediment yield in the catchments using some fundamental factors of the geology (rock and soil), topography (elevation and slope), climate (precipitation and temperature), and the land use types (Bagherzadeh and Daneshvar 2011). The model calculates the erosion coefficient $(Z)$ in a catchment using the below Equation (Dragičević et al. 2018:

$$
Z=Y \times X \times(\varphi+\sqrt{I})
$$

Where $Y$ is the soil erodibility coefficient based on the soil data, $X$ is the soil protection coefficient based on the land use types, $\varphi$ is the coefficient of the type of erosion processes based on the remotely sensed observation and surface geology, and I is the average slope gradient of the catchment (\%). According to the method proposed by Gavrilović (1988), the coefficients of soil erodibility $(Y)$ and soil protection (X), and type of erosion process $(\varphi)$ could be considered using descriptive and numerical evaluations represented in Table 1, which have been illustrated by de Vente and Poesen (2005), Haghizadeh et al. (2009), and Dragičević et al. (2018).

After that, the model can estimate the watershed sediment production (W) in cubic meters per year $\left(\mathrm{m}^{3} / \mathrm{yr}\right)$ using the below Equation (Dragičević et al. 2018, Berteni and Grossi 2020)

$$
W=T \times H \times \pi \times \sqrt{Z^{3}} \times A
$$


Where $\mathrm{T}$ is the temperature coefficient (equal 1.18) that is calculated based on the mean annual temperature in the study area $\left(13{ }^{\circ} \mathrm{C}\right)$ using follows (Berteni and Grossi 2020):

$$
T=\sqrt{\frac{t}{10}+0.1}
$$

Where $H$ is the mean annual precipitation $(400 \mathrm{~mm}), \pi$ is equal to $3.14, Z$ is the erosion coefficient calculated in Equation (1), and $A$ is the study area $\left(\mathrm{km}^{2}\right)$. Ultimately, the value of $W$ can estimate the total production of soil erosion and sediment deposits in a watershed (Bagherzadeh and Daneshvar 2011).

\subsection{Flood model}

The rational flood model (RFM) is the empirical equations, which have been interpreted in several studies, e.g., Thompson (2006), Devi et al. (2019), and Cheah et al. (2019), to estimate the runoff coefficient and peak flood discharge using the land use and land terrain characteristics (Aja et al. 2020). The RFM is expressed by the below Equation (Parak and Pegram 2006):

$$
Q p=R C \times P I \times A \times 3.6
$$

Where Qp is the flood peak discharge in cubic meters per second (m3/s), RC is the runoff coefficient (unitless), PI is the precipitation intensity in millimeters per hour $(\mathrm{mm} / \mathrm{h})$ that is determined based on the time-series linear trend (Shanableh et al. 2018), and $\mathrm{A}$ is the catchment surface area in squared kilometers $\left(\mathrm{km}^{2}\right)$.

According to the precipitation data (2016-2020) and its coefficient of determination (R2>0.69), the mean annual precipitation of the region was estimated as $400 \mathrm{~mm}$, and the maximum anomaly of hourly precipitation was obtained as $37.8 \mathrm{~mm}$, which can be considered as precipitation intensity (PI) in the study area (Table 2). Furthermore, the runoff coefficient (RC) can be determined in each catchment by overlapping the aforementioned intensity classes of soil units, land-use/ land-cover types, rainfall rates, and slope ranges, which are shown in Table 3 (e.g., Mousavi et al. 2019, Aja et al. 2020). For this purpose, the land cover, slope range, and soil unit layers are surveyed in each catchment in GIS using the Zonal Statistics extension to estimate a real RC value, which is the important parameter for flood control projects (Zeinali et al. 2019) 


\section{Results and Discussion}

\subsection{Description of the environmental parameters}

The geological surface of the study region is covered mainly by limestone formation and lime members (>75\%), such as dolomite and lime-shale, and lime-sandstone (Fig. 4). The oldest rock units observed at the study area are Jurassic dolomites of the Mozduran formation (in the sub-catchments 2, 3, 4, 5, 6, and 8), and the youngest are the Cretaceous aged formation of Atamir and Abderaz (in the sub-catchments 13 and 14) (GSI 2015). The catchment has been suffered by anticline and fault lines, formed mainly by alternations between lime-sandstone of Shurijeh and dolomite rock of Mozduran (such as Istisu fault transferred from the middle part of the catchment). The network of junctions on carbonate rocks with high porosity, such as Karst shafts and waterfalls over Tirgan formation, are surveyed in sub-catchment 9. Karst valleys in the eastern part of Kopet-Dagh, such as the Kalat region, are combined with layers of lime members (Daneshvar et al. 2014).

The general physiographic trend of the catchment extends in the southwesternnortheastern direction with an average of $8.5 \mathrm{Km}$ length from the upstream to downstream, and the slope classes over $15 \%$ are covered $>75 \%$ of the total area (Fig. 5). The main soil units (based on global soil grids) are classified into Mollisols and Inceptisols (in the elevations with permeable units of sandy loams) and Entisols (in the downstream with the impervious texture of clay loams) (Fig. 6). Land covers are categorized as the forest of Junipers ( $\sim 38 \%$ of the catchment in the upstream), bare land of rock faces ( $\sim 31 \%$ of the catchment in the upstream), pasture land of Artemisia and Agropyron ( $23 \%$ of the catchment in the middle parts), and farmland of dry farming ( $\sim 8 \%$ of the catchment in the downstream) (Fig. 7). Data-layer values for different classes of the environmental parameters in the study area are shown in Table 4.

\subsection{Estimation of the EPM}

The mean values of the erosion parameters and coefficients of the EPM model were estimated for each sub-catchment in Table 5, including surface area $(A)$, slope gradient $(I)$, soil protection coefficient $(X)$, soil erodibility coefficient $(Y)$, erosion coefficient $(Z)$, and type of erosion processes $(\varphi)$. The mean value of slope range in the study area was 
calculated $14 \%$, where the highest and the lowest values, with $24 \%$ and $4 \%$, belong to sub-catchments 5 and 14, respectively. The most values of soil protection coefficient $(X=0.8$ : bare land covers) were determined for sub-catchments in the upstream (over $1400 \mathrm{~m}$ a.s.l), while the most values of soil erodibility coefficient ( $Y=1.3$ : shale and marl landforms) and type of erosion processes ( $\varphi=0.8$ : gully and surface erosion) were verified for sub-catchments in the downstream (below $1400 \mathrm{~m}$ a.s.l). Besides, the values of erosion coefficient and watershed sediment production $(W)$ were estimated for the study sub-catchments, revealing the very highest erosion coefficient and sedimentation production $\left(Z>1.5\right.$ and $W>3000 \mathrm{~m}^{3} /$ year) for sub-catchments 4,5 , and 7 . Theoretically, the mentioned erosion coefficient and sedimentation production are categorized as severe and excessive erosion potential (Dragičević et al. 2018).

The erosion susceptibility model was categorized in Fig. 8 through heavy, moderate, and slight classes. The heavy class of erosion susceptibility (with sediment production of $2127-4529 \mathrm{~m}^{3}$ per year) belongs to seven catchments with $58.2 \%$ of the total study area. The moderate and slight classes of erosion susceptibility (with sediment production of 1103-2048 and 309-882 $\mathrm{m}^{3}$ per year) belong to seven catchments with $19.0 \%$ and $22.8 \%$ of the total study area, respectively. The mean value of sediment production in all subcatchments is estimated to equal $2120 \mathrm{~m}^{3}$ per year (Table 6).

\subsection{Estimation of the RFM}

Same as the erosion model, the mean values of the flood parameters and coefficients of the RFM model were estimated for each sub-catchment in Table 7, including surface area $(A)$, runoff coefficient $(R C)$, and precipitation intensity $(P I)$. The mean value of the runoff coefficient was calculated at 0.35 , where the highest and the lowest values, with 0.65 and 0.15 , belong to sub-catchments 5 and 12 , respectively. The most values of the runoff coefficient $(R C>0.5)$ were determined for sub-catchments in the upstream (over $1400 \mathrm{~m}$ a.s.1), which have the highest slope ranges and rock outcrops over the hard dolomite landforms.

In this regard, the values of flood peak discharge $(Q p)$ were estimated for the study subcatchments, revealing the very highest flood discharge $\left(>75 \mathrm{~m}^{3} / \mathrm{s}\right)$ for sub-catchments 4 , 5, 6, and 7. On this basis, the flood susceptibility model was categorized in Fig. 9 
through three classes of heavy, moderate, and slight. The heavy class of flood susceptibility (with a discharge of 84.37-141.52 $\mathrm{m}^{3}$ per second) belongs to four catchments with $40.4 \%$ of the total study area. The moderate and slight classes of flood susceptibility (with a peak discharge of 25.86-65.99 and 8.57-23.81 and $\mathrm{m}^{3}$ per year) belong to seven catchments with $44.3 \%$ and $15.3 \%$ of the total study area, respectively. The mean value of flood peak discharge in all sub-catchments is estimated to equal $53.92 \mathrm{~m}^{3}$ per second (Table 8 ).

\subsection{Discussion on the susceptibility evaluation models}

The statistical results revealed that the heavy classes of erosion and flood susceptibility (with sediment production of 2127-4529 $\mathrm{m}^{3}$ per year and flood discharge of 84.37$141.52 \mathrm{~m}^{3}$ per second) includes $40.4-58.2 \%$ of the total study area dominantly in the upstream sub-catchments of the Qarasu catchment. Based on the spatial survey, the heaviest flood discharge and erosion potential prone zones are observed corresponding on the Mozduran and Shurijeh formations composed mainly of dolomite, limestone, and shale on the bare landforms and steep slopes. This result is accordant with the previous works investigating the erosion susceptibility in the other catchments of the Kopet-dagh, such as Bagherzadeh and Daneshvar (2011). In the vice versa, areas with the slight flood discharge and erosion potential classes are observed in the sub-catchments, which have been covered fully by forest or dense pastureland without relevant relation with rock and soil units.

The similar distribution of heavy and slight susceptibilities of flood and erosion models in the study area can be examined by correlation test to reveal possible relationships. In this regard, a correlation test using the Pearson test $(\mathrm{p}<0.05)$ was assumed to analyze the relationships between EPM and RFM outputs (watershed sediment production: $W$ and flood peak discharge: $Q p$ ). The correlation analysis was carried out based on the models' output in 14 sub-catchments. Table 9 revealed a strong, significant, and direct association ( $\mathrm{R}$ equal to 0.705 ) between $W$ and $Q p$ at the $99 \%$ confidence level. Hence, the flood and erosion susceptibility evaluations demonstrated the study area's co-related spatial and statistical outcomes. In the mountainous catchments, higher flood peaks and runoff flow can indicate the high erosion and sediment yield transportation (Dragičević 
et al. 2019). Consequently, the results of our research can indicate the prioritization of the sub-catchments based on their sensitivity and susceptibility to occurrences of soil erosion and flood events. Hence, the study area's sub-catchments of 8, 12, and 14 can be considered low susceptible zones against the flood and erosion hazards.

\subsection{Validation of the models}

In recent researches, the cumulative amounts for each erosion and flood susceptibility have exposed the susceptible zones in the downstream part of the watersheds (e.g., Dodangeh et al. 2020, Hosseini et al. 2020, Mosavi et al. 2020a). However, our study assumes the susceptibility of each sub-catchment independently to reveal the important role of runoff coefficient $(R C)$ and erosion coefficient $(Z)$ in the flood and erosion susceptibility evaluation. The $R C$ value is an important parameter in flood discharge estimation, and high $R C$ is associated with high flood discharge and susceptibility (Hung et al. 2018, Zeinali et al. 2019). Meanwhile, the $Z$ value is the main model equation that gives numerical and descriptive information about the susceptibility of a given area to erosion processes (Dragičević et al. 2018). These parameters can essentially represent the actual state of the study region toward the model variable test, which can be used in the model validation procedure, namely the receiver operating characteristic curve (ROC-curve). In this section, the ROC-curves for both susceptibility models were produced in Fig. 10. The model validity explained the AUC (area under the curve) values averagely equal to 0.898 and 0.917 for erosion and flood susceptibility evaluation (i.e., EPM and RFM), explaining the models' very good performance and excellent performance sensitivities.

\section{Conclusion}

The main aim of this study was to evaluate erosion and flood susceptibility using empirical models of EPM and RFM to prioritize the GIS-based prone zones in a catchment of the Kopet-Dagh Mountains. The required soil erosion and flood susceptibility evaluation data were obtained from some global datasets with spatial grid pixels and time series. The important characteristic of the study area was its geological setting of limestone units and carbonate rocks, which were susceptible to erosion and 
flood events. The results revealed that the heavy classes of erosion and flood susceptibility (with sediment production of 2127-4529 $\mathrm{m}^{3}$ per year and flood discharge of $84.37-141.52 \mathrm{~m}^{3}$ per second) includes $40.4-58.2 \%$ of the total study area dominantly in the upstream catchments. The similar distribution of heavy and slight susceptibilities of flood and erosion models in the study area was examined by correlation test, exposing a strong, significant, and direct association ( $\mathrm{R}$ equal to 0.705 ) between $W$ and $Q p$ at the 99\% confidence level. Therefore, the present study assumed the susceptibility of each sub-catchment independently to reveal the important role of runoff coefficient $(R C)$ and erosion coefficient $(Z)$ in the flood and erosion susceptibility evaluation. These parameters were represented as the actual state of the study region toward the model variable test to validate the models using ROC-curve. The model validity explained the AUC (area under the curve) values averagely equal to 0.898 and 0.917 for erosion and flood susceptibility evaluations (i.e., EPM and RFM), explaining the models' very good performance and excellent performance sensitivities.

The practical implication of this research depends on prioritizing susceptible zones for spatial development and tourism plans of the study area by providing proper environmental insight for their managers, planners, investors, and stockholders. Meanwhile, the theoretical implication of the research is to provide more interpretations for EPM and RFM models for localizing and generalizing the equations and coefficients in future studies. Further research can be carried out based on the combination of other environmental hazards, such as earthquakes and landslides and flood and soil erosion, in the susceptibility evaluation models of the watersheds. Some studies have shown a significant relationship between land-use change, flash floods, and soil erosion (Ferreira et al. 2015, Mohammadi et al. 2021). Hence, future researches can consider the role of land-use changes in the erosion and flood susceptibility evaluation within the time series.

\section{Acknowledgements}

Deputy of Research and Technology of Khorramabad Azad University supported this research. We thank our colleagues who provided insight and expertise and greatly assisted the research. 


\section{References}

Ahmadi M, Minaei M, Ebrahimi O, Nikseresht M (2020). Evaluation of WEPP and EPM for improved predictions of soil erosion in mountainous watersheds: A case study of Kangir River basin, Iran. Modeling Earth Systems and Environment, 6: 2303-2315.

Ahmadi B, Moradkhani H (2019). Revisiting hydrological drought propagation and recovery considering water quantity and quality. Hydrol Proc, 33: 1492-1505.

Aja D, Elias E, Obiahu OH (2020). Flood risk zone mapping using rational model in a highly weathered Nitisols of Abakaliki Local Government Area, South-eastern Nigeria. Geology, Ecology, and Landscapes, 4(2): 131-139.

Alavi M, Vaziri H, Seyed-Emami K, Lasemi Y (1997). The Triassic and associated rocks of the Aghdarband area in central and north eastern Iran as remnant of the southern Turanian active continental margin. Geol Soc Am Bull, 109: 1563-1575.

Amiri M, Pourghasemi HR (2020). Mapping and preparing a susceptibility map of gully erosion using the MARS model. In: Gully erosion studies from India and surrounding regions. Cham: Springer; p. 405-413.

Auerswald K, Fiener P, Martin W, Elhaus D (2014). Use and misuse of the K factor equation in soil erosion modeling: an alternative equation for determining USLE nomograph soil erodibility values. Catena, 118: 220-225.

Avand M, Janizadeh S, Naghibi SA, Pourghasemi HR, Khosrobeigi Bozchaloei S, Blaschke T. (2019). A comparative assessment of random forest and k-nearest neighbor classifiers for gully erosion susceptibility mapping. Water, 11: 2076.

Azareh A, Rafiei Sardooi E, Choubin B, Barkhori S, Shahdadi A, Adamowski J, Shamshirband S (2019). Incorporating multi-criteria decision-making and fuzzy-value functions for flood susceptibility assessment. Geocarto International, https://doi.org/10.1080/10106049.2019.1695958.

Bagherzadeh A, Daneshvar MRM (2011). Sediment yield assessment by EPM and PSIAC models using GIS data in semi-arid region. Frontiers of Earth Science, 5(2): 2072016. 
Bagherzadeh A, Daneshvar MRM (2013). Evaluation of sediment yield and soil loss by the MPSIAC model using GIS at Golestan watershed, northeast of Iran. Arabian Journal of Geosciences, 6: 3349-3362.

Baskan O, Cebel H, Akgul S, Erpul G (2010). Conditional simulation of USLE/RUSLE soil erodibility factor by geostatistics in a Mediterranean Catchment, Turkey. Environmental Earth Sciences, 60(6): 1179-1187.

Berberian M, King GCP (1981). Towards a paleogeographic and tectonic evolution of Iran. Canadian J Earth Sci, 18: 210-265.

Berteni F, Grossi G (2020). Water soil erosion evaluation in a small alpine catchment located in northern italy: potential effects of climate change. Geosciences, 10: 386.

Brierley GI, Fryirs KL (2006). Geomorphology and river management. Blackwell Publication, Hoboken, p 387.

Bui DT, Panahi M, Shahabi H, Singh VP, Shirzadi A, Chapi K, Khosravi K, Chen W, Panahi S, Li S, et al. (2018). Novel hybrid evolutionary algorithms for spatial prediction of floods. Scientific Reports, 8(1): 15364.

Cheah R, Billa L, Chan A, Teo FY, Pradhan B, Alamri AM (2019). Geospatial modelling of watershed peak flood discharge in Selangor, Malaysia. Water, 11: 2490.

Coppus R, Imeson AC (2002). Extreme events controlling erosion and sediment transport in a semi-arid sub-Andean valley. Earth Surface Processes and Landforms, 27 (13): $1365-1375$.

Dai SB, Lu XX (2010). Sediment deposition and erosion during the extreme flood events in the middle and lower reaches of the Yangtze River. Quaternary International, 226: 4-11.

Daneshvar MRM, Bagherzadeh A (2012). Evaluation of sediment yield in PSIAC and MPSIAC models by using GIS at Toroq Watershed, northeast of Iran. Frontiers of Earth Science, 6(1): 83-94. 
Daneshvar MRM, Behniafar A, Ghanbarzadeh H (2014). Geomorphological explanation of karstic drainage sensitivity toward anthropogenic pollutants in Kardeh catchment, NE Iran. International Journal of Environmental Protection and Policy, 2(3): 113-117.

De Vente J, Poesen J (2005). Predicting soil erosion and sediment yield at the basin scale: scaleissues and semi-quantitative models. Earth Sci Rev, 71(1-2): 95-125.

Devi NN, Sridharan B, Kuiry SN (2019). Impact of urban sprawl on future flooding in Chennai city, India. Journal of Hydrology, 574: 486-496.

Dodangeh E, Choubin B, Eigdir AN, Nabipour N, Panahi M, Shamshirband S, Mosavi A (2020). Integrated machine learning methods with resampling algorithms for flood susceptibility prediction. Science of the Total Environment, 705: 135983.

Dragičević N, Karleuša B, Ožanić N (2018). Modification of erosion potential method using climate and land cover parameters. Geomatics, Natural Hazards and Risk, 9(1): 1085-1105.

Dragičević N, Karleuša B, Ožanić N (2019). Different approaches to estimation of drainage density and their effect on the erosion potential method. Water, 11: 593.

Ebrahimi M, Nejadsoleymani H, Daneshvar MRM (2019). Land suitability map and ecological carrying capacity for the recognition of touristic zones in the Kalat region, Iran: a multi-criteria analysis based on AHP and GIS. Asia-Pacific Journal of Regional Science, 3: 697-718.

Ebrahimi M, Nejadsoleymani H, Sadeghi A, Daneshvar MRM (2021). Assessment of the soil loss-prone zones using the USLE model in northeastern Iran. Paddy and Water Environment 19, 71-86.

Feng X, Wang Y, Cheng L, Fu B, Bai G (2010). Modeling soil erosion and its response to land-use change in hilly catchments of the Chinese Loess Plateau. Geomorphology, $118(3-4), 239-248$.

Fox D, Berolo W, Carrega P, Darboux F (2006). Mapping erosion risk and selecting sites for simple erosion control measures after a forest fire in Mediterranean France. Earth Surface Processes and Landforms, 31(5): 606-621. 
Ferreira V, Panagopoulos T, Cakula A, Andrade R, Arvela A (2015). Predicting soil erosion after land use changes for irrigating agriculture in a large reservoir of southern Portugal. Agriculture and Agricultural Science Procedia, 4: 40-49.

Gavrilović Z (1988). The use of an empirical method (Erosion Potential Method) for calculating sediment production and transportation in unstudied or torrential streams. In: Proceeding of International Conference of River Regime, 18-20 May, Wallingford, England, 411-422.

Gayen A, Pourghasemi HR, Saha S, Keesstra S, Bai S (2019). Gully erosion susceptibility assessment and management of hazard-prone areas in India using different machine learning algorithms. Sci Total Environ. 668: 124-138.

GSI (2015). Geological sheets at scale 1:100,000 Archived by Geological Survey of Iran. http://www.gsi.ir. Accessed 2020.

Haghizadeh A, Teang Shui L, Godarzi E (2009). Forecasting sediment a with erosion potential method with emphasis on land use changes at basin, electronic. Journal of Geotechnical Engineering, 14: 1-12.

Hosseini FS, Choubin B, Mosavi A, Nabipour N, Shamshirband S, Darabi H, Haghighi AT (2020). Flash flood hazard assessment using ensembles and Bayesian-based machine learning models: application of the simulated annealing feature selection method. Sci Total Environ, 711: 135161.

Huang L, He B, Han L, Liu J, Wang H, Chen Z (2017). A global examination of the response of ecosystem water use efficiency to drought based on MODIS data. Sci Total Environ, 601-602: 1097-1107.

Janizadeh S, Avand M, Jaafari A, Phong T, Van Bayat M, Ahmadisharaf E, Prakash I, Pham BT, Lee S (2019). Prediction success of machine learning methods for flash flood susceptibility mapping in the Tafresh Watershed, Iran. Sustainability. 11(19): 5426.

Lazzari M, Gioia D, Piccarreta M, Danese M, Lanorte A (2015). Sediment yield and erosion rate estimation in the mountain catchments of the Camastra artificial reservoir (Southern Italy): A comparison between different empirical methods. Catena,127: 323339. 
Mahboubi A, Harami RM, Daneshvar PM, Nadjafi M, Brenner RL (2006). Upper Maastrichtian depositional environments and sea-level history of the Kopet-Dagh Intracontinental Basin, Kalat Formation, NE Iran. Facies, 52: 237-248.

Mihu-Pintilie A, Cîmpianu CI, Stoleriu CC, Pérez MN, Paveluc LE (2019). Using highdensity lidar data and $2 \mathrm{~d}$ stream flow hydraulic modeling to improve urban flood hazard maps: a HEC-RAS multi-scenario approach. Water, 11: 1832.

Mohammadi M, Darvishan AK, Spalevic V, Dudic B, Billi P (2021). Analysis of the impact of land use changes on soil erosion intensity and sediment yield using the IntErO model in the Talar Watershed of Iran. Water, 13: 881.

Moradi HR, Avand MT, Janizadeh S (2019). Landslide susceptibility survey using modeling methods. Amsterdam: Elsevier, p. 259-276.

Mosavi A, Golshan M, Janizadeh S, Choubin B, Melesse AM, Dineva AA (2020a). Ensemble models of GLM, FDA, MARS, and RF for flood and erosion susceptibility mapping: a priority assessment of sub-basins. Geocarto International, https://doi.org/10.1080/10106049.2020.1829101.

Mosavi A, Sajedi-Hosseini F, Choubin B, Taromideh F, Rahi G, Dineva AA (2020b). Susceptibility mapping of soil water erosion using machine learning models. Water. 12(7): 1995.

Mousavi SM, Roostaei S, Rostamzadeh H (2019). Estimation of flood land use/land cover mapping by regional modelling of flood hazard at sub-basin level case study: Marand basin. Geomatics Nat Hazards Risk, 10(1): 1155-1175.

NASA (2011). The Advanced Spaceborne Thermal Emission and Reflection Radiometer (ASTER) Global Digital Elevation Model (GDEM) Archived by National Aeronautics and Space Administration (NASA). http://www.gdem.aster.ersdac.or.jp. Accessed 2020. Noori H, Siadatmousavi SM, Mojaradi B (2016). Assessment of sediment yield using RS and GIS at two sub-basins of Dez Watershed, Iran. International Soil and Water Conservation Research, 4: 199-206. 
Pandey A, Chowdary VM, Mal BC (2007). Identification of critical erosion prone areas in the small agricultural watershed using USLE, GIS and remote sensing. Water Resource Management, 21: 729-746.

Parak M, Pegram GG (2006). The rational formula from the runhydrograph. Water SA, 32(2): 163-180.

Pham BT, Avand M, Janizadeh S, Phong TV, Al-Ansari N, Ho LS, Das S, Le HV, Amini A, Bozchaloei SK, et al. (2020). GIS based hybrid computational approaches for flash flood susceptibility assessment. Water, 12(3): 683.

Schoenau S, Thapa PK, Bárdossy A (2008). Erosion and sediment yield estimation for flood protection. In: Proceeding of fourth international symposium on flood defense: managing flood risk, reliability and vulnerability, Toronto, Ontario, Canada.

Shanableh A, Al-Ruzouq R, Yilmaz AG, Siddique M, Merabtene T, Imteaz MA (2018). Effects of land cover change on urban floods and rainwater harvesting: a case study in Sharjah, UAE. Water, 10: 631.

Singh RK, Panda RK, Satapathy KK, Ngachan SV (2011). Simulation of runoff and sediment yield from a hilly watershed in the eastern Himalaya, India using the WEPP model. Journal of Hydrology, 405(3-4): 261-276.

Spalevic V, Barovic G, Vujacic D, Curovic M, Behzadfar M, Djurovic N, Dudic B, Billi P (2020). The impact of land use changes on soil erosion in the river basin of Miocki Potok, Montenegro. Water, 12: 2973.

Srivastava A, Wu JQ, Elliot WJ, Brooks ES (2015). Enhancements to the Water Erosion Prediction Project (WEPP) for modeling large snow-dominated mountainous. Forest Watersheds: EWRI Watershed Management Conference, Reston, VA, 209-228.

$\mathrm{Su}$ W (2017). Measuring the past 20 years of urban-rural land growth in flood-prone areas in the developed Taihu Lake watershed, China. Frontiers of Earth Science, 11: 361-371.

Thompson DB (2006). The rational method, regional regression equations, and sitespecific flood-frequency relations. Research Report 4405-1, Texas Tech University, https://tu-ir.tdl.org/handle/2346/22794. 
$505 \quad$ Tingsanchali T (2012). Urban flood disaster management. Procedia Engineering, 32: 25$506 \quad 37$.

507 White SM (2005). Sediment yield prediction and modeling. In: Anderson M (ed.), $508 \quad$ Encyclopaedia of Hydrological Sciences. Wiley \& Sons.

509 Zeinali V, Vafakhah M, Sadeghi SH (2019). Impact of urbanization on temporal 510 distribution pattern of storm runoff coefficient. Environ Monit Assess, 191: 595.

511 Zhao G, Pang B, Xu Z, Yue J, Tu T (2018a). Mapping flood susceptibility in 512 mountainous areas on a national scale in China. Sci Total Environ. 615: 1133-1142.

513 Zhao W, Wei H, Jia L, Daryanto S, Zhang X, Liu Y (2018b). Soil erodibility and its 514 influencing factors on the Loess Plateau of China: a case study in the Ansai watershed. $515 \quad$ Solid Earth, 9: 1507-1516.

516 
Table 1: Descriptive and numerical evaluation for the erosion parameters

\begin{tabular}{cc}
\hline Parameters and classes & Value \\
\hline Soil protection $(\boldsymbol{X})$ & \\
Forest & 0.2 \\
Pasture land & 0.4 \\
Farm land & 0.6 \\
Bare land & 0.8 \\
Soil erodibility $(\boldsymbol{Y})$ & \\
Dolomite & 0.4 \\
Limestone & 0.6 \\
Sandstone & 0.8 \\
Conglomerate & 1.0 \\
Shale and marl & 1.3 \\
Loess deposits & 1.8 \\
Type of erosion $(\boldsymbol{\varphi})$ & \\
Hard rocks & 0.2 \\
Karstic erosion & 0.5 \\
Gully and surface erosion & 0.8 \\
\hline
\end{tabular}

519

520

Table 2: Rainfall data in the study area (2016-2020)

\begin{tabular}{ccc}
\hline Year & $\begin{array}{c}\text { Mean annual } \\
(\mathrm{mm})\end{array}$ & $\begin{array}{c}\text { Max. hourly } \\
(\mathrm{mm} / \mathrm{h})\end{array}$ \\
\hline 2016 & 414.8 & 25.2 \\
2017 & 241.0 & 14.2 \\
2018 & 507.6 & 50.8 \\
2019 & 453.1 & 56.8 \\
2020 & 391.1 & 42.2 \\
Mean & 401.5 & 37.8 \\
\hline
\end{tabular}

Table 3: Determination of the runoff coefficients $(R C)$ in the catchments based on the land covers, soil units and slope ranges

\begin{tabular}{|c|c|c|c|c|c|c|}
\hline \multirow[b]{3}{*}{ Soil units } & \multicolumn{6}{|c|}{ Soil units } \\
\hline & \multicolumn{3}{|c|}{ Permeable (Molli and Inceptisols) } & \multicolumn{3}{|c|}{ Impervious (Entisols) } \\
\hline & Slope $<5 \%$ & $5-15 \%$ & $>15 \%$ & Slope $<5 \%$ & $5-15 \%$ & $>15 \%$ \\
\hline Forest & 0.10 & 0.15 & 0.20 & 0.20 & 0.25 & 0.30 \\
\hline Pasture & 0.15 & 0.20 & 0.25 & 0.25 & 0.30 & 0.40 \\
\hline Farm & 0.30 & 0.40 & 0.55 & 0.60 & 0.70 & 0.75 \\
\hline Bare & 0.50 & 0.55 & 0.65 & 0.65 & 0.70 & 0.75 \\
\hline
\end{tabular}


$529 \quad$ Table 4: Data-layer values for different classes of the environmental parameters in the $530 \quad$ study area

\begin{tabular}{|c|c|c|}
\hline \multirow{2}{*}{ Parameters and classes } & \multicolumn{2}{|c|}{ Total area } \\
\hline & $\left(\mathrm{km}^{2}\right)$ & $(\%)$ \\
\hline \multicolumn{3}{|l|}{ Elevation (m) } \\
\hline $1000-1200$ & 1.41 & 9.92 \\
\hline $1200-1400$ & 1.92 & 13.50 \\
\hline $1400-1700$ & 4.72 & 33.19 \\
\hline $1700-2000$ & 3.65 & 25.67 \\
\hline $2000-2500$ & 2.52 & 17.72 \\
\hline \multicolumn{3}{|l|}{ Slope $(\%)$} \\
\hline $0-5$ & 3.15 & 22.15 \\
\hline $5-15$ & 4.12 & 28.97 \\
\hline$>15$ & 6.95 & 48.87 \\
\hline \multicolumn{3}{|l|}{ Geology (formations) } \\
\hline Dolomite and hard limestone (Mozduran: Jmz) & 7.45 & 52.39 \\
\hline Lime and sandstone (Shurijeh: Ksh) & 1.36 & 9.56 \\
\hline Thick bedded limestone (Tirgan: Kt) & 1.52 & 10.69 \\
\hline Shale and marl (Sarcheshmeh: Ksr) & 1.24 & 8.72 \\
\hline Shale and siltstone (Sanganeh: Ksn) & 0.98 & 6.89 \\
\hline Lime and conglomerate (Atamir: Kat) & 1.02 & 7.17 \\
\hline Lime and shale (Abderaz: Kad) & 0.65 & 4.57 \\
\hline \multicolumn{3}{|l|}{ Land cover (types) } \\
\hline Forest & 5.41 & 38.05 \\
\hline Pasture land & 3.24 & 22.78 \\
\hline Farm land & 1.13 & 7.95 \\
\hline Bare land & 4.44 & 31.22 \\
\hline \multicolumn{3}{|l|}{ Soil (units) } \\
\hline Entisols & 1.45 & 10.20 \\
\hline Inceptisols & 5.66 & 39.80 \\
\hline Mollisols & 7.11 & 50.00 \\
\hline
\end{tabular}


534 Table 5: Estimation of the parameters of the EPM in the sub-catchments, including 535 surface area $(A)$, slope gradient $(I)$, soil protection coefficient $(X)$, soil erodibility 536 coefficient $(Y)$, erosion coefficient $(Z)$, type of erosion processes $(\varphi)$, and watershed $537 \quad$ sediment production $(W)$

\begin{tabular}{cccccccc}
\hline Sub-catchment & $\begin{array}{c}\mathrm{A} \\
\left(\mathrm{km}^{2}\right)\end{array}$ & $\begin{array}{c}\mathrm{I} \\
(\%)\end{array}$ & $\begin{array}{c}\mathrm{X} \\
(-)\end{array}$ & $\begin{array}{c}\mathrm{Y} \\
(-)\end{array}$ & $\begin{array}{c}\mathrm{Z} \\
(-)\end{array}$ & $\begin{array}{c}\varphi \\
(-)\end{array}$ & $\begin{array}{c}\mathrm{W} \\
\left(\mathrm{m}^{3} / \mathrm{s}\right)\end{array}$ \\
\hline 1 & 1.06 & 14 & 0.4 & 0.7 & 1.15 & 0.4 & 1932 \\
2 & 1.47 & 16 & 0.2 & 0.5 & 0.44 & 0.4 & 632 \\
3 & 0.78 & 20 & 0.8 & 0.4 & 1.50 & 0.2 & 2127 \\
4 & 1.60 & 20 & 0.8 & 0.4 & 1.54 & 0.3 & 4529 \\
5 & 1.05 & 24 & 0.8 & 0.4 & 1.66 & 0.3 & 3330 \\
6 & 1.85 & 18 & 0.5 & 0.4 & 0.88 & 0.2 & 2276 \\
7 & 1.24 & 18 & 0.5 & 0.7 & 1.61 & 0.4 & 3749 \\
8 & 0.72 & 16 & 0.2 & 0.5 & 0.44 & 0.4 & 309 \\
9 & 1.22 & 12 & 0.3 & 0.6 & 0.72 & 0.5 & 1103 \\
10 & 0.95 & 12 & 0.3 & 1.3 & 1.64 & 0.7 & 2957 \\
11 & 0.42 & 8 & 0.5 & 1.3 & 2.21 & 0.6 & 2048 \\
12 & 0.55 & 4 & 0.3 & 1.3 & 1.05 & 0.7 & 880 \\
13 & 0.82 & 8 & 0.5 & 1.0 & 1.80 & 0.8 & 2929 \\
14 & 0.50 & 4 & 0.4 & 1.0 & 1.12 & 0.8 & 882 \\
\hline
\end{tabular}

540 Table 6: Soil erosion susceptibility classifications in the study area

\begin{tabular}{cccc}
\hline $\begin{array}{c}\text { Susceptibility } \\
\text { classes }\end{array}$ & $\begin{array}{c}\text { No. of } \\
\text { sub-catchment }\end{array}$ & Area $\left(\mathrm{Km}^{2}\right)$ & \% of total area \\
\hline Slight & 4 & 3.24 & 22.8 \\
Moderate & 3 & 2.70 & 19.0 \\
Heavy & 7 & 8.28 & 58.2 \\
Total & 14 & 14.22 & 100 \\
\hline
\end{tabular}


Table 7: Estimation of the parameters of the RFM in the sub-catchments, including 546 surface area $(A)$, runoff coefficient $(R C)$, precipitation intensity $(P I)$, and flood peak $547 \quad$ discharge $(Q p)$

\begin{tabular}{ccccc}
\hline Sub-catchment & $\begin{array}{c}\mathrm{A} \\
\left(\mathrm{km}^{2}\right)\end{array}$ & $\begin{array}{c}\mathrm{RC} \\
(-)\end{array}$ & $\begin{array}{c}\mathrm{PI} \\
(\mathrm{mm} / \mathrm{h})\end{array}$ & $\begin{array}{c}\mathrm{Qp} \\
\left(\mathrm{m}^{3} / \mathrm{s}\right)\end{array}$ \\
\hline 1 & 1.06 & 0.2 & 37.8 & 28.85 \\
2 & 1.47 & 0.2 & 37.8 & 40.01 \\
3 & 0.78 & 0.65 & 37.8 & 68.99 \\
4 & 1.60 & 0.65 & 37.8 & 141.52 \\
5 & 1.05 & 0.65 & 37.8 & 92.87 \\
6 & 1.85 & 0.5 & 37.8 & 125.87 \\
7 & 1.24 & 0.5 & 37.8 & 84.37 \\
8 & 0.72 & 0.2 & 37.8 & 19.6 \\
9 & 1.22 & 0.2 & 37.8 & 33.2 \\
10 & 0.95 & 0.2 & 37.8 & 25.86 \\
11 & 0.42 & 0.15 & 37.8 & 8.57 \\
12 & 0.55 & 0.15 & 37.8 & 11.23 \\
13 & 0.82 & 0.45 & 37.8 & 50.21 \\
14 & 0.50 & 0.35 & 37.8 & 23.81 \\
\hline
\end{tabular}

Table 8: Flood susceptibility classifications in the study area

\begin{tabular}{cccc}
\hline $\begin{array}{c}\text { Susceptibility } \\
\text { classes }\end{array}$ & $\begin{array}{c}\text { No. of } \\
\text { sub-catchment }\end{array}$ & Area $\left(\mathrm{Km}^{2}\right)$ & \% of total area \\
\hline Slight & 4 & 2.18 & 15.3 \\
Moderate & 6 & 6.30 & 44.3 \\
Heavy & 4 & 5.74 & 40.4 \\
Total & 14 & 14.22 & 100 \\
\hline
\end{tabular}


555 Table 9: Correlation between outcomes of erosion (watershed sediment production: $W$ )

556 and flood (flood peak discharge: $Q p$ ) susceptibilities in 14 sub-catchments of the study $557 \quad$ area

\begin{tabular}{ccc}
\hline Outcome & Statistical test & $\begin{array}{c}Q p \\
(\mathrm{RFM} \text { model })\end{array}$ \\
\hline & Pearson Correlation $(\mathrm{R})$ & 0.705 \\
$W$ & $\mathrm{R}^{2}$ & 0.497 \\
$($ EPM model $)$ & Sig. & 0.005 \\
& $\mathrm{~N}$. & 14 \\
\hline
\end{tabular}

558

559 


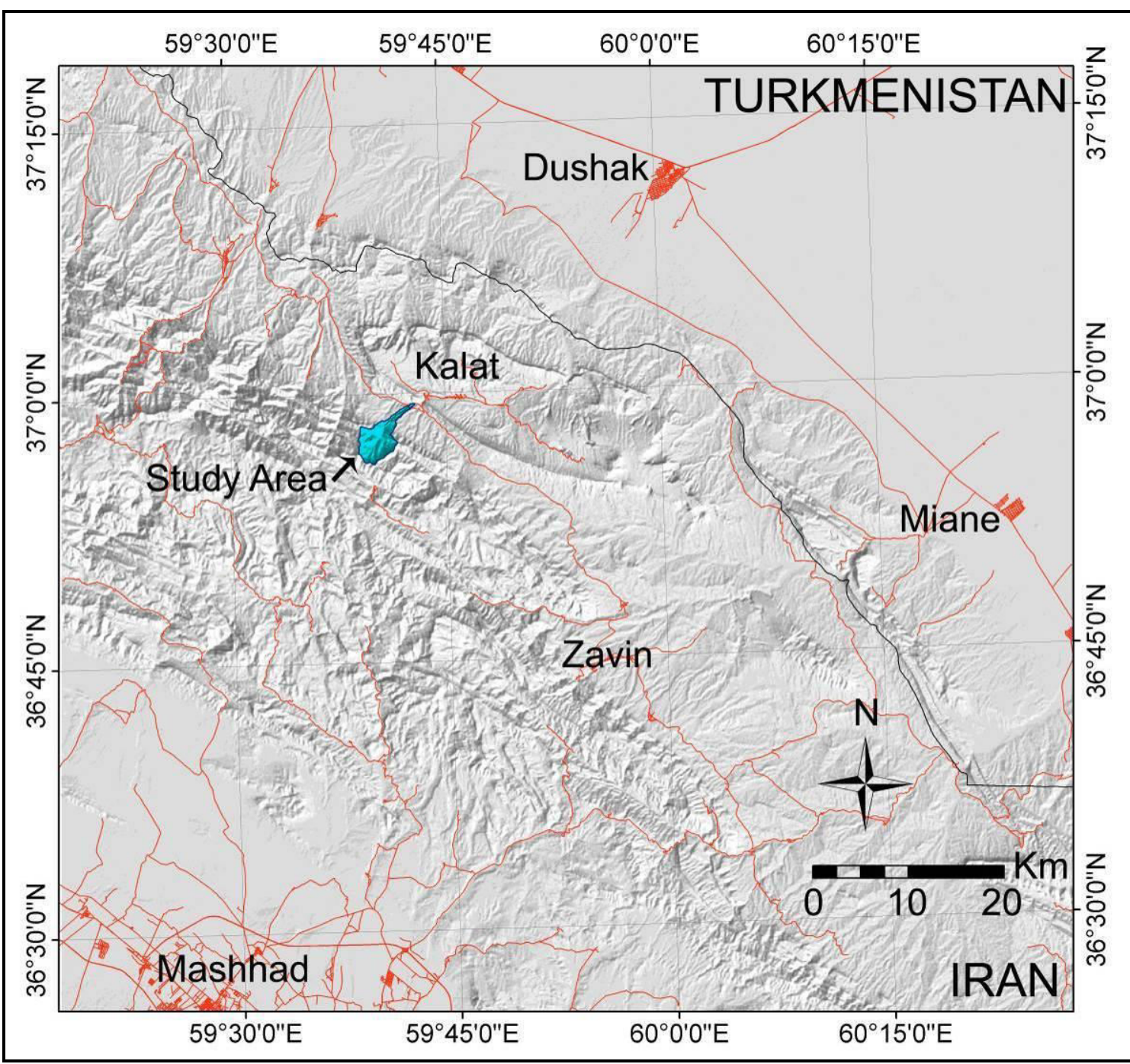

Fig. 1: Geographical position of the study area 


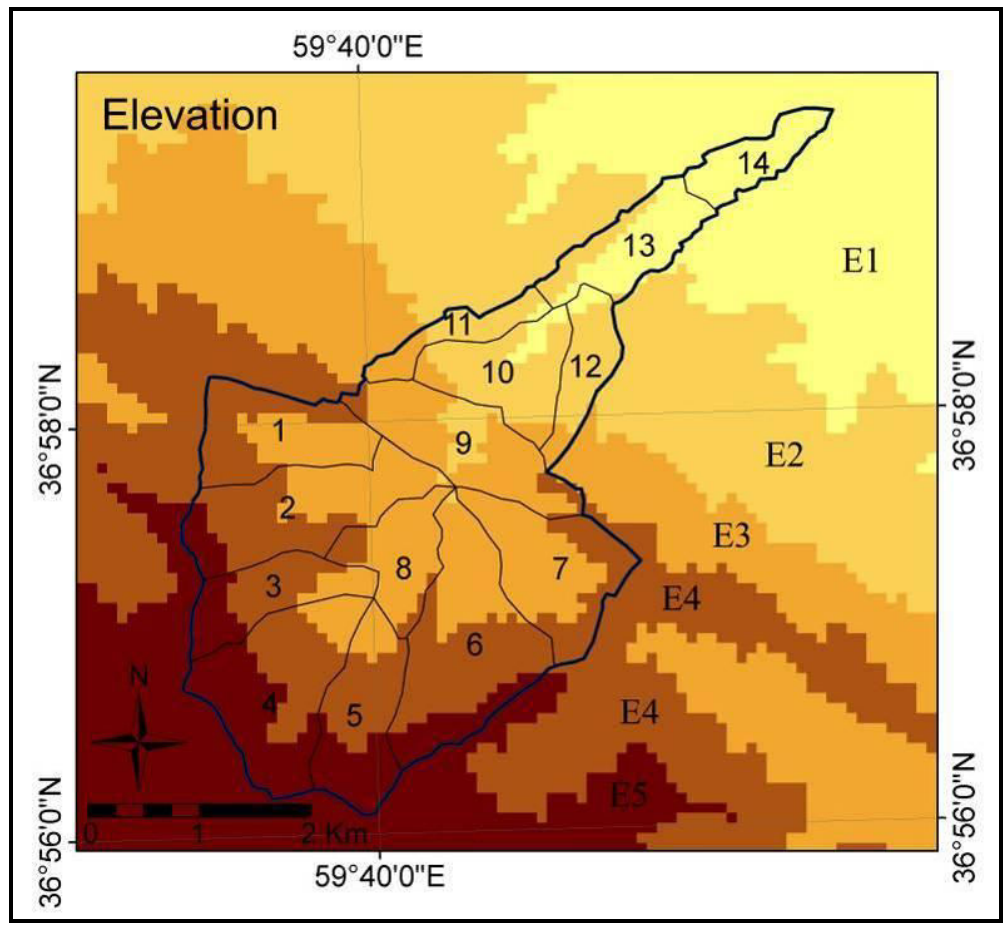

Fig. 2: Elevation classes map, including E1: 1000-1200 m, E2: 1200-1400 m, E3: 14001700 m, E4: 1700-2000 m, and E5: 2000-2500 m

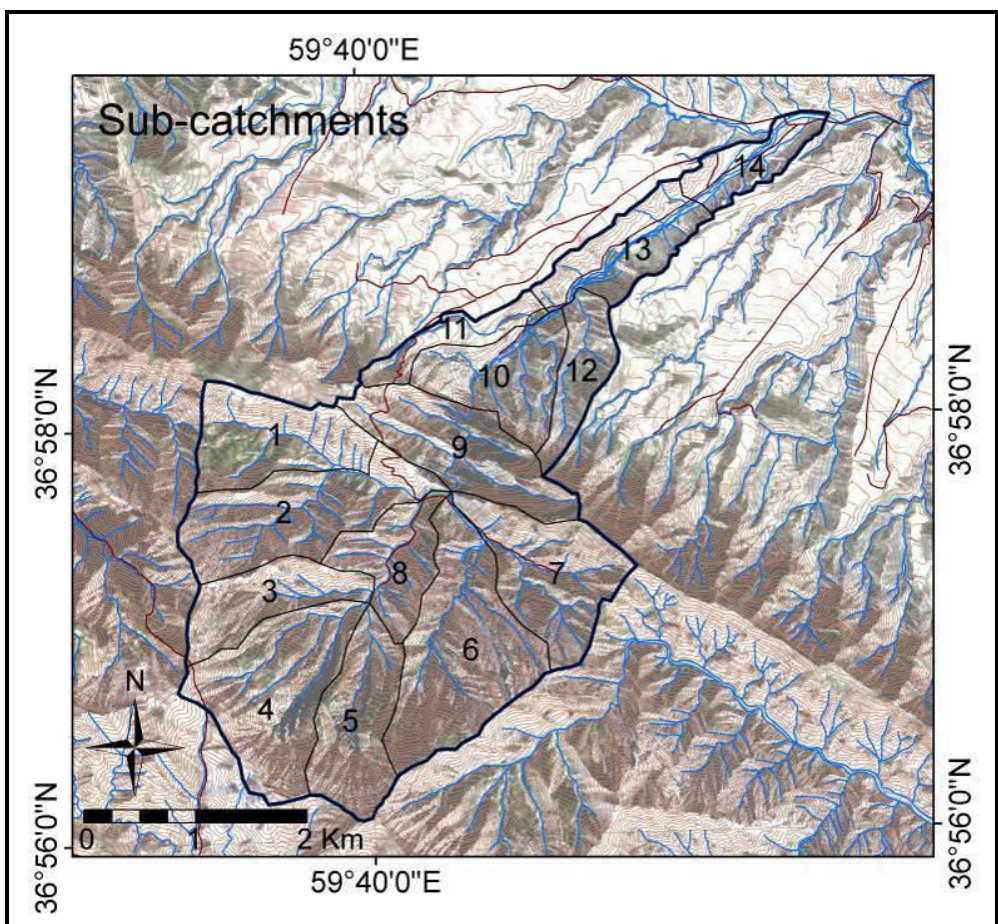

Fig. 3: Sub-catchments of the study area based on the satellite image (Google Erath) 


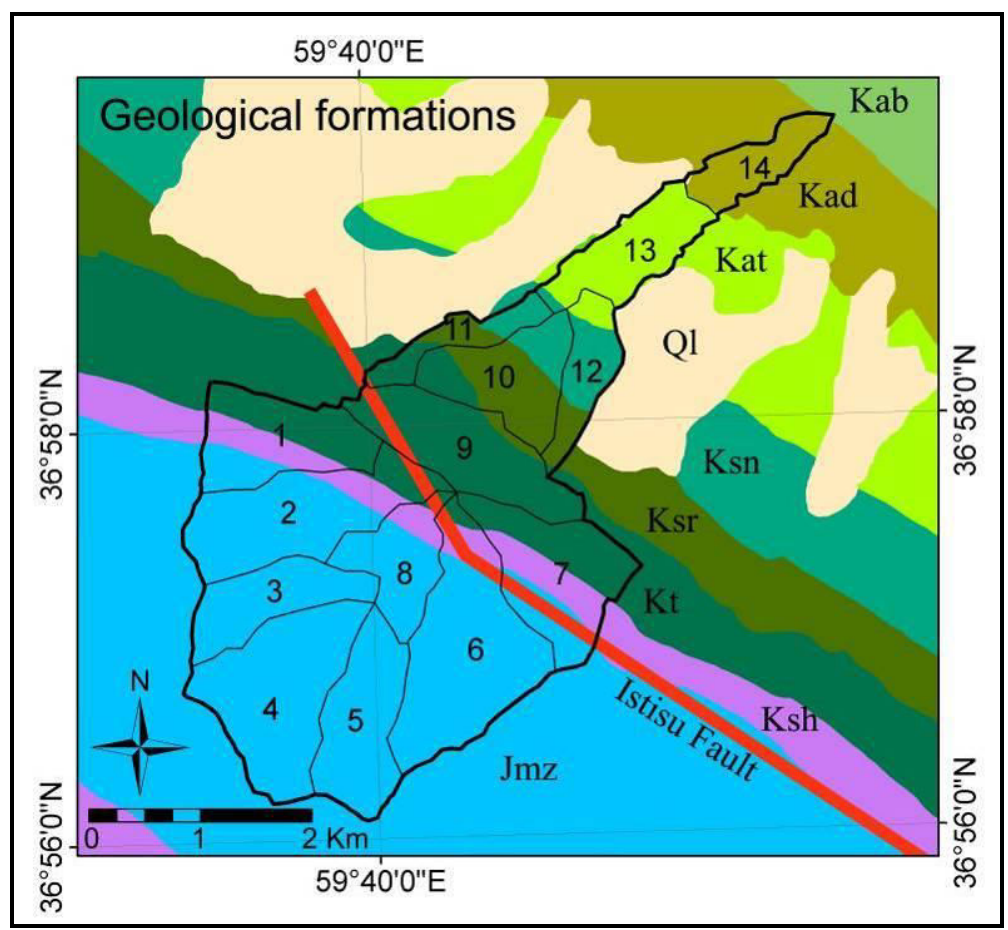

Fig. 4: Geological map, including Jmz: Mozduran, Ksh: Shurijeh, Kt: Tirgan, Ksr:

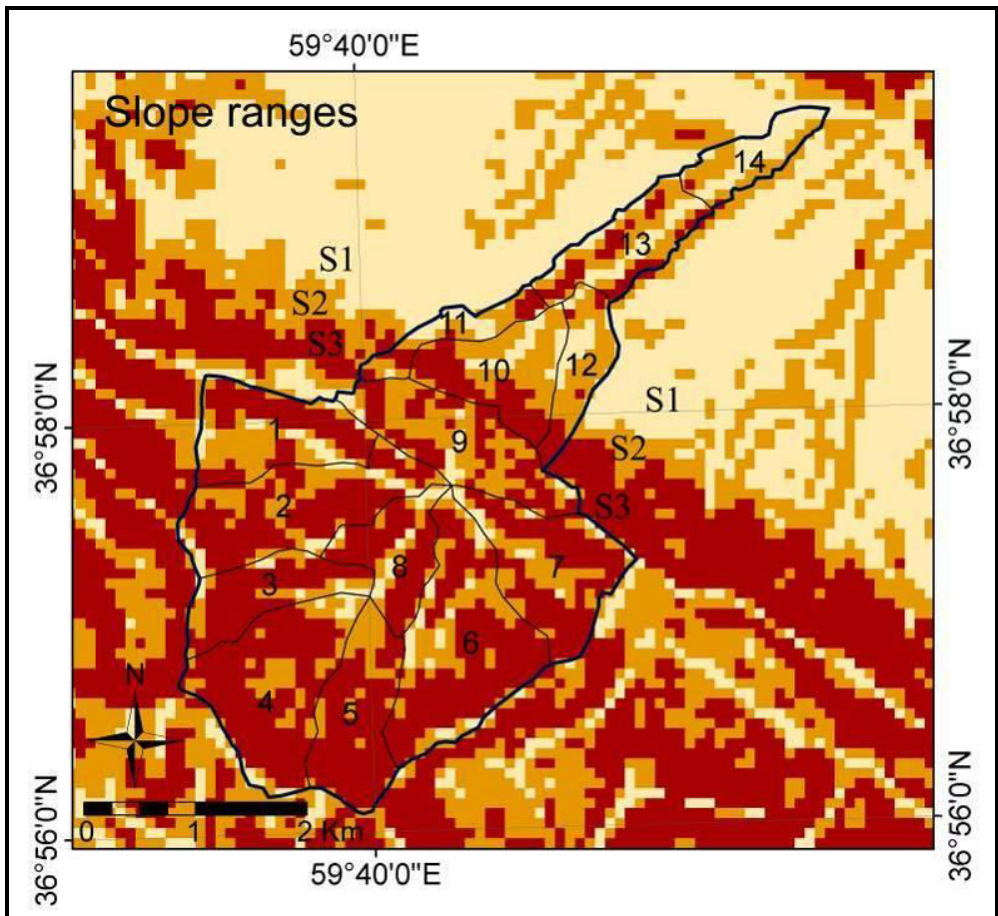

Fig. 5 Slope ranges map, including S1: $<5 \%, \mathrm{~S} 2: 5-15 \%$, and S3: $>15 \%$ 


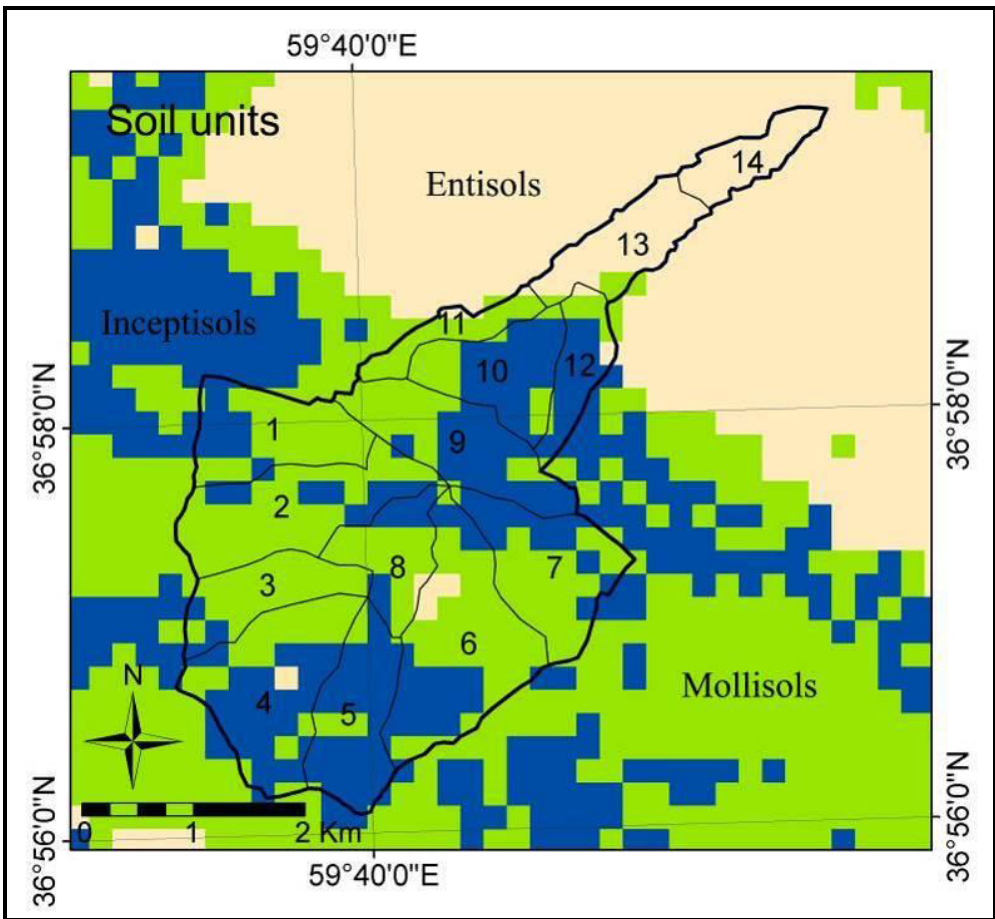

Fig. 6: Soil units map, including mollisols, inceptisols, and entisols

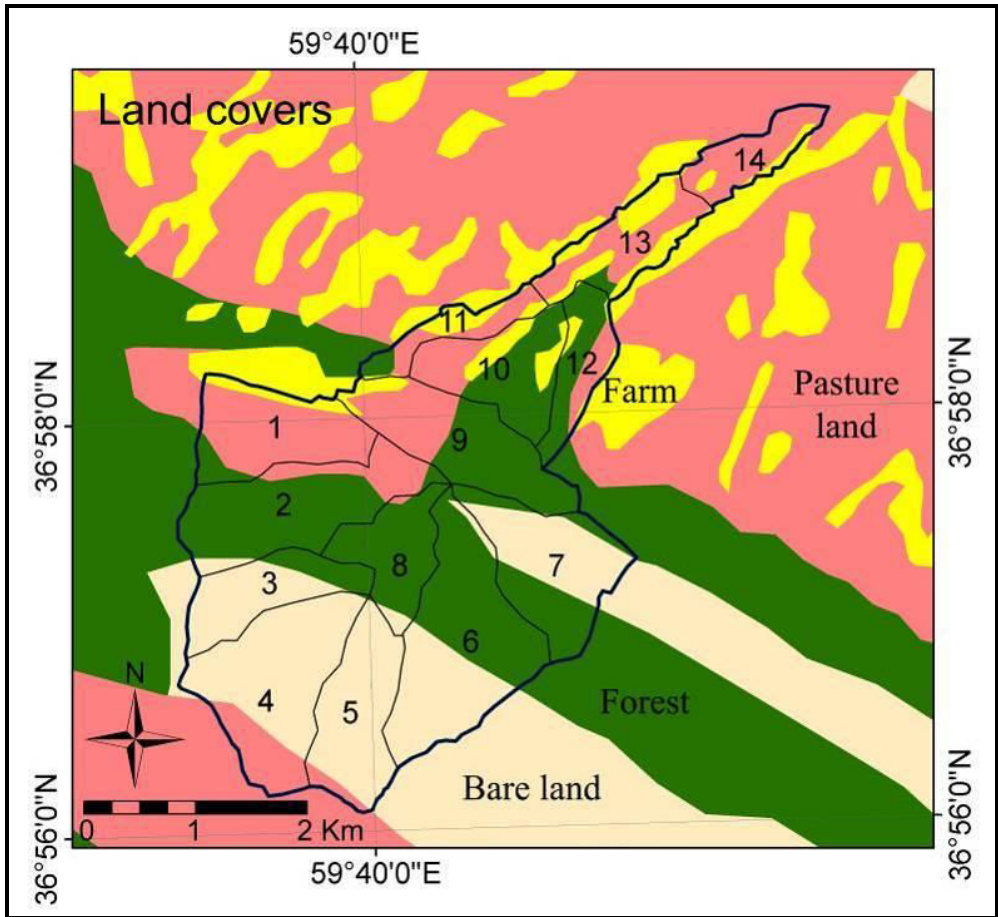

Fig. 7: Land covers map, including forest of Junipers, pasture land of Artemisia and Agropyron, farmland of dry farming, and bare land of rock faces 


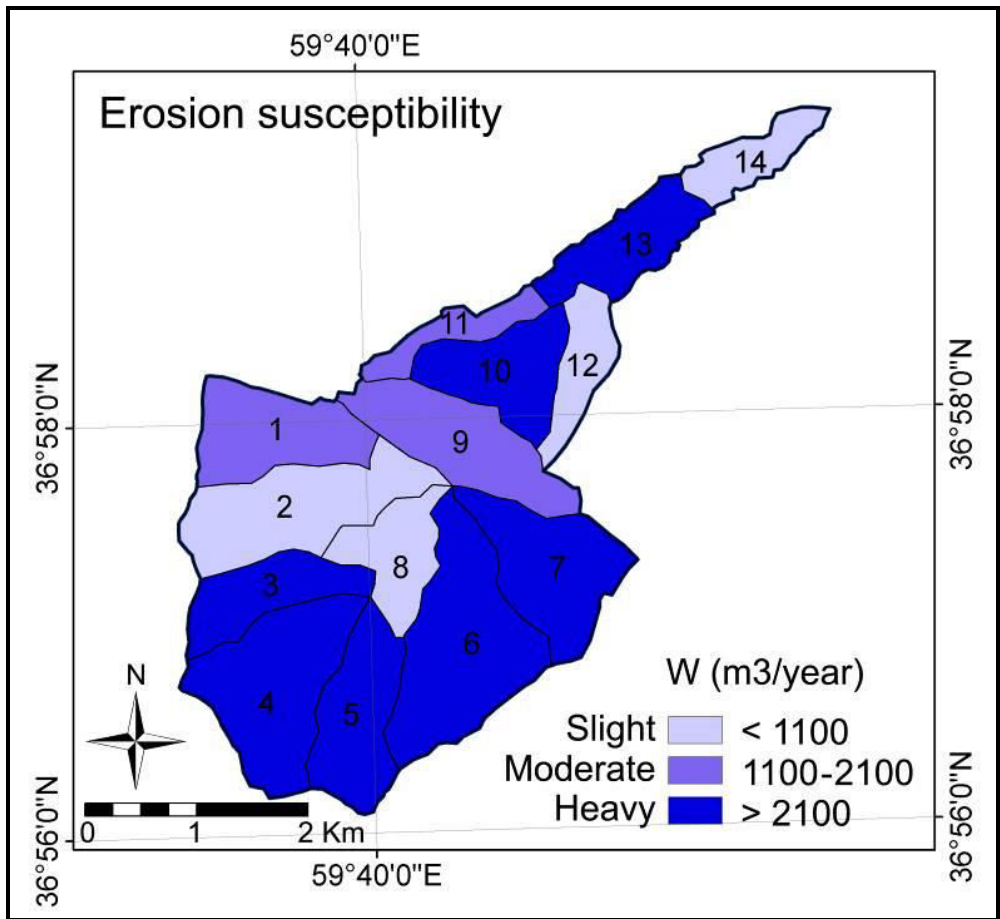

Fig. 8: Erosion susceptibility evaluation map

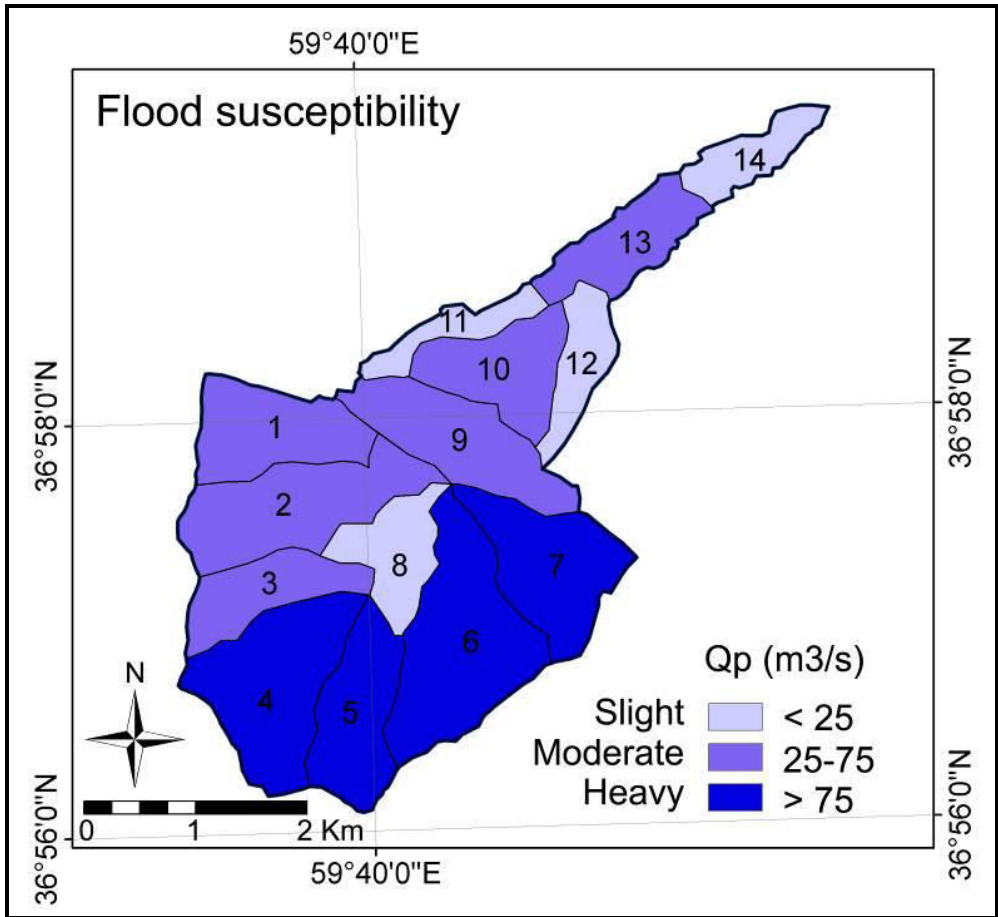

Fig. 9: Flood susceptibility evaluation map 


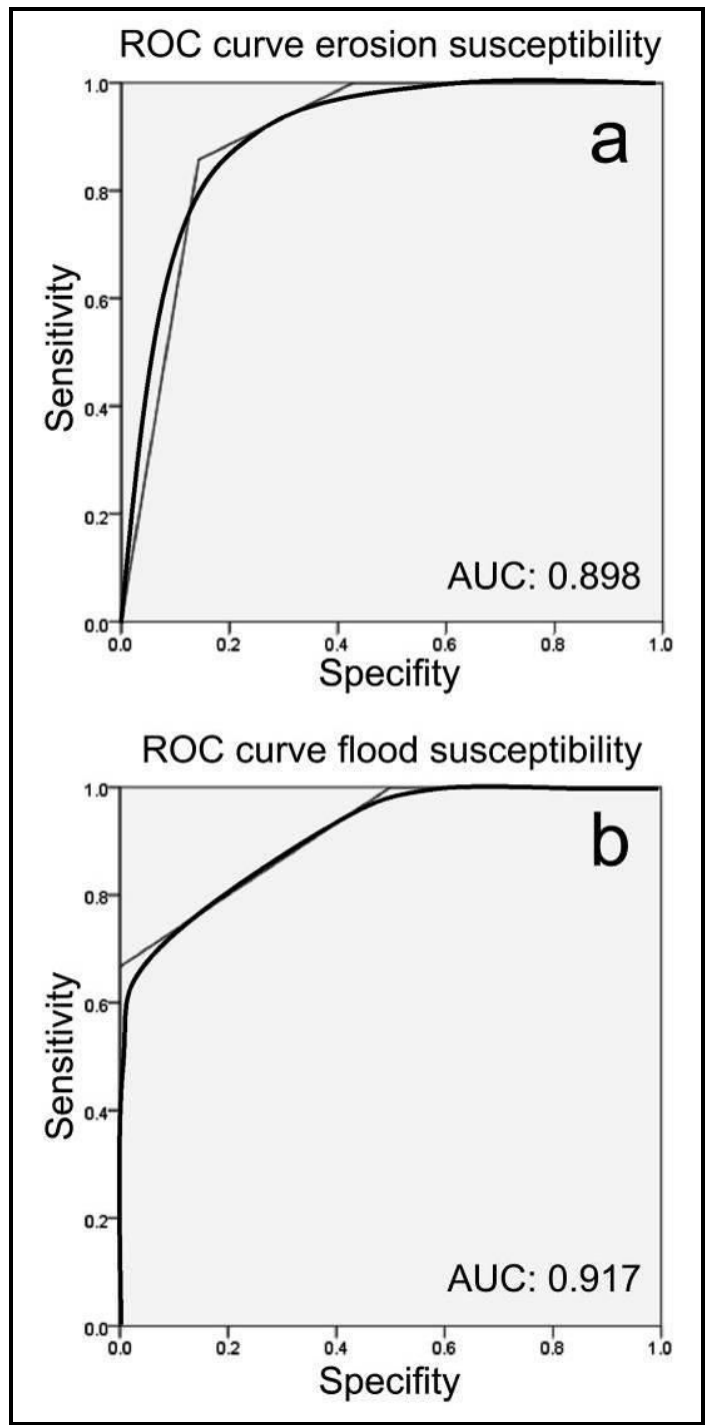

591

Fig. 10: ROC-curve of the susceptibility models for a. soil erosion susceptibility and $\mathbf{b}$. 